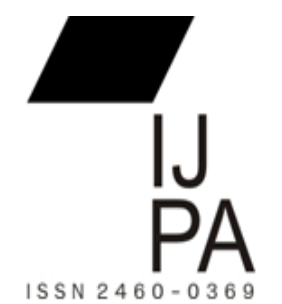

\title{
PENGARUH PELAYANAN DAN LOYALITAS PEGAWAI TERHADAP KEPUASAN MASYARAKAT DALAM MENGURUS KARTU TANDA PENDUDUK DI KELURAHAN KELAPA GADING TIMUR DI JAKARTA UTARA
}

\section{Andi Marta, Dodi Faedlulloh}

\author{
Satuan Polisi Pamong Praja (Satpol-PP) Jakarta Utara \\ andi.marta@gmail.co.id
}

\begin{abstract}
This study uses primary data through surveys, survey research methods can be analyzed in accordance with the wishes and needs of researchers, for example, to see the influence of the independent variables or to predict future behavior.The aim of this study was to determine the effect of service and loyalty of employees to the satisfaction of the public in obtaining an identity card in the Village East in Kelapa Gading, North Jakarta. People's satisfaction is a construct that stands alone and is affected by the service. Services can also affect employee loyalty directly, if the performance according to expectations, the people will be satisfied, if the performance to exceed expectations, then people will feel very satisfied (delighted). The approach used in this study is a quantitative analysis, using primary data obtained from the questionnaire. other than that of primary data obtained from the questionnaire that was distributed to the respondents. Then the data that has been processed is used to analyze the research hypothesis.T test results in partial positive and significant impact services to the satisfaction of the people in the care of the National Identity Card, as well as Employee Loyalty positive and significant impact on the care of the Public Satisfaction Pendududuk Identity Card. From the simultaneous analysis showed that Services and Employee Loyalty positive and significant impact to the satisfaction of the Society.
\end{abstract}

Keywords: Care, Employee Loyalty, and Community Satisfaction. 
Abstrak, Penelitian ini menggunakan data primer melalui survey, metode penelitian survey bisa dianalisa sesuai dengan keinginan dan kebutuhan peneliti, misalnya untuk melihat pengaruh independen variabel atau untuk meramalkan perilaku di masa datang Tujuan dari pada penelitian ini adalah untuk mengetahui pengaruh pelayanan dan loyalitas pegawai terhadap kepuasan masyarakat dalam mengurus kartu tanda penduduk di Kelurahan Kelapa Gading Timur di Jakarta Utara. Kepuasan masyarakat adalah merupakan konstruk yang berdiri sendiri dan dipengaruhi oleh pelayanan. Pelayanan juga dapat mempengaruhi loyalitas pegawai secara langsung, jika kinerja sesuai harapan maka masyarakat akan merasa puas, jika kinerja sampai melebihi harapan, maka masyarakat akan merasa sangat puas (delighted). Pendekatan yang digunakan dalam penelitian ini adalah analisis kuantitatif, dengan menggunakan data primer yang diperoleh dari hasil penyebaran kuisioner. selain itu dari data primer yang diperoleh dari kusioner yang telah disebarkan ke responden. Kemudian data yang telah diolah dipakai untuk menganalisis hipotesis penelitian. Hasil uji t secara parsial variabel Pelayanan berpengaruh positif dan signifikan terhadap Kepuasan masyarakat dalam mengurus Kartu Tanda Penduduk, begitu pula Loyalitas Pegawai berpengaruh positif dan signifikan terhadap Kepuasan Masyarakat dalam mengurus Kartu Tanda Pendududuk. Dari analisis secara simultan diperoleh bahwa Pelayanan dan Loyalitas Pegawai berpengaruh positif dan signifikan terhadap Kepuasan Masyarakat.

Kata Kunci: Pelayanan, Loyalitas Pegawai, dan Kepuasan Masyarakat

\section{PENDAHULUAN}

Pemberian pelayanan kepada masyarakat secara umum belum menunjukkan kinerja sebagai yang diharapkan. Hal ini dapat dilihat antara lain dari banyaknya pengaduan atau keluhan dari masyarakat kepada Kementrian Pendayagunaan Aparatur Negara (Menpan) seperti menyangkut prosedur dan mekanisme kerja pelayanan yang berbelit-belit, tidak transparan, kurang informatif, kurang akomodatif, kurang konsisten, terbatasnya fasilitas, sarana dan prasarana pelayanan, sehingga tidak menjamin kepastian (hukum, waktu, dan biaya) serta masih banyak dijumpai praktek pungutan liar serta tindakan-tindakan yang 
berindikasi penyimpangan dan korupsi, kolusi, dan nepotisme (KKN). Undang-Undang Republik Indonesia Nomor 25 Tahun 2009 tentang Pelayanan Publik yang mendefinisikan bahwa pelayanan publik adalah kegiatan atau rangkaian kegiatan dalam rangka pemenuhan kebutuhan pelayanan sesuai dengan peraturan perundangan- undangan bagi setiap warga negara dan penduduk atas barang, jasa atau pelayanan administratif yang disediakan oleh penyelenggara pelayanan publik. Sedangkan dalam Keputusan Menteri Pendayagunaan Aparatur Negara Nomor 63 tahun 2003 yang dimaksud pelayanan publik adalah segala bentuk pelayanan yang dilaksanakan oleh instansi pemerintah baik di pusat dan daerah dalam bentuk barang atau jasa, baik dalam rangka upaya pemenuhan kebutuhan masyarakat maupun dalam rangka pelaksanaan ketentuan peraturan perundang-undangan.

Menurut Boediono (2003:60) Secara umum pelayanan dapat diartikan sebagai usaha apa saja yang memaksimalkan kepuasan masyarakat dengan demikian dalam menyajikan pelayanan hendaknya dapat melengkapi dengan sesuatu yang tidak hanya dinilai dengan materi semata, tetapi ketulusan, keikhlasan dan integritas yang ditunjukan pemberi pelayanan jauh lebih penting. Dalam hal ini dapat diartikan bahwa masyarakat akan merasa puas apabila menerima pelayanan yang baik dari pegawai dan loyal khususnya pada saat melakukan proses pengurusan Kartu Tanda Penduduk (KTP) pada pelayanan yang diberikan kepada masyarakat sesuai dengan yang diharapkan. Masyarakat juga akan memberikan penilaian secara langsung dari apa yang telah mereka terima dari pelayanan yang telah diberikan pegawai di Kelurahan Kelapa Gading Timur Jakarta Utara. Selanjutnya menurut Soetopo dalam Napitupulu (2007:164) pelayanan adalah suatu usaha untuk membantu menyiapkan dan mengurus apa yang diperlukan orang lain dalam memenuhi kebutuhanya, pelayanan juga dapat disebut suatu proses membantu orang lain dengan cara-cara tertentu yang memerlukan kepekaan dan hubungan interpersonal serta loyalitas para pegawai agar terpenuhinya rasa kepuasan dan keberhasilan dari orang yang pemberi pelayanan dengan penerima layanan. Pelayanan Kartu Tanda Penduduk (KTP) yang dilakuan oleh pegawai di Kelurahan Kelapa Gading Timur di Jakarta Utara merupakan salah satu kegiatan pelayanan pemerintah di bidang administrasi kependudukan. Pelayanan tersebut adalah merupakan pencatatan dan pengesahan peristiwa penting penduduk untuk menuju kepastian hukum dan tertibnya administrasi kependudukan melalui 
pencatatan peristiwa kelahiran, perkawinan, perceraian, kematian, pengesahan dan pengakuan anak.

Kartu Tanda Penduduk (KTP) merupakan hak asasi setiap warga Negara guna memperoleh akses terhadap fasilitas-fasilitas publik. Tanpa Kartu Tanda Penduduk (KTP) warga akan mengalami berbagai hambatan dalam memperoleh fasilitas-fasilitas penting yang diperlukan untuk menjamin keperluan hidup, misalnya kesulitan mendapatkan kredit dari bank atau lembaga keuangan lainnya, bepergian, mendapatkan sambungan listrik, saluran air bersih dan lain-lain. Singkatnya, warga yang tidak memiliki Kartu Tanda Penduduk (KTP) akan mengalami banyak hambatan-hambatan yang berkaitan dengan aspek-aspek hukum, ekonomi maupun sosial. Kartu Tanda Penduduk (KTP) juga memiliki arti penting bagi pemerintah, yaitu sebagai salah satu cara untuk menciptakan tertib administrasi kependudukan, pengendalian penduduk, data kependudukan yang akurat.

Berdasarkan hasil observasi di lokasi penelitian terdapat gejala-gejala atau fenomena yaitu lambatnya pelayanan yang diberikan oleh pegawai, kurangnya loyalitas sehingga mengurangi pelaksanaan proses kependudukan, cenderung lamban, sehingga memperlambat penyelesaian pekerjaan, penempatan pegawai tidak sesuai dengan latar belakang pendidikan sehingga akan berpengaruh terhadap kepuasan masyarakat. Hal tersebut perlu dilakukan langkah-langkah yang nyata untuk merubah paparan dari fenomena di atas serta kedepannya agar dapat memberikan pelayanan yang optimal dan loyalitas pegawai di Kelurahan Kelapa Gading Timur di Jakarta Utara guna tercapainya kepuasan masyarakat.

Berdasarkan hal-hal tersebut di atas, maka rumusan masalah dalam penelitian ini adalah sebagai berikut: 1 . Apakah ada pengaruh pelayanan terhadap kepuasan masyarakat dalam pengurusan Kartu Tanda Penduduk (KTP) di Kelurahan Kelapa Gading Timur di Jakarta Utara ? 2. Apakah ada pengaruh loyalitas pegawai terhadap kepuasan masyarakat dalam pengurusan Kartu Tanda Penduduk (KTP) di Kelurahan Kelapa Gading Timur di Jakarta Utara ? 3. Apakah ada pengaruh pelayanan dan loyalitas pegawai secara bersamasama terhadap kepuasan masyarakat dalam pengurusan Kartu Tanda Penduduk (KTP) di Kelurahan Kelapa Gading Timur di Jakarta Utara? 


\section{KAJIAN TEORITIS}

\section{Pelayanan Masyarakat}

Pelayanan menurut Cristhoper H. Lovelock (1996 : 11), menyebutkan bahwa pelayanan berkaitan dengan proses kegiatan dimana produk yang dihasilkan bukan berbentuk benda yang dapat dikonsumsi tetapi berupa pengalaman yang dapat mempengaruhi kepuasan seseorang. Pelayanan kadangkala dikatakan sebagai suatu proses kegiatan dari pada sebuah produk, sebuah proses yang menggambarkan adanya masukan yang kemudian diubah menjadi keluaran. Pelayanan menurut Sampara Lukman (1999 : 6) menyatakan bahwa pelayanan sebagai suatu kegiatan yang urutan kegiatan yang terjadi dalam interaksi langsung antara seseorang dengan orang lain atau mesin secara fisik dan menyediakan kepuasan konsumen. Menurut H.A.S. Munir (1995:204) mendifinisikan pelayanan adalah proses yang kegiatannya diarahkan secara khusus pada terselenggaranya pelayanan guna memenuhi kepentingan umum atau kepentingan perorangan, melalui cara-cara yang tepat dan memuaskan pihak yang dilayani. Berdasarkan pengertian tersebut di atas, maka penulis menyimpulkan bahwa pelayanan dapat diartikan sebagai kegiatan pelayanan yang diberikan kepada seseorang, masyarakat atau organisasi untuk mendapatkan kepuasan.

\section{Loyalitas Pegawai}

Memiliki pegawai yang loyal adalah tujuan akhir dari semua pelanggan tetapi kebanyakan dari pelanggan atau produsen tidak mengetahui bahwa loyalitas pegawai dapat dibentuk melalui beberapa tahapan. Mulai dari mencari calon pegawai potensial sampai dengan Advocate Customer yang akan membawa keuntungan bagi masyarakat. Oliver (2007:392) mendefinisikan loyalitas sebagai komitmen untuk bertahan hidup secara mendalam dengan melakukan pembelian ulang atau berlangganan kembali dengan produk atau jasa terpilih secara konsisten dimasa yang akan datang, meskipun pengaruh situasi dan usaha-usaha pemasaran mempunyai potensi untuk menyebabkan perubahan prilaku. Evans dan Laskin dalam Sekitto Haruna (2007:30) menyatakan bahwa konsep loyalitas lebih mengarah kepada perilaku (behaviour) dibandingkan dengan sikap (attitude) dan seorang pegawai yang loyal akan memperlihatkan perilaku yang didefinisikan sebagai pelayanan yang teratur dan diperlihatkan sepanjang waktu oleh unit pembuat keputusan. Sedangkan Griffin 
(2005:18) menyatakan bahwa pembeli yang melakukan pembelian pertama kali akan melalui lima langkah ; pertama menyadari adanya suatu produk, kedua melakukan pembelian awal. Selanjutnya pembeli bergerak melalui dua fase yang pertama disebut evaluasi setelah pembelian (pospurchase evaluation) dan yang kedua disebut keputusan untuk melakukan pembelian ulang (decision to repurchase). Apabila keputusannya adalah untuk melakukan pembelian ulang, kelima langkah tersebut akhirnya berlanjut. Sedangkan karakteristik loyalitas pegawai merupakan aset ternilai bagi organisasi, karena karakteristik dari pegawai yang loyal menurut Griffin (2005:31) antara lain : 1.Melakukan pelayanan secara teratur. 2. Melayani diluar lini produk atau jasa. 3. Menolak produk lain.4. Menunjukkan kelebihan dari tarikan persaingan tidak terpengaruh oleh tarikan persaingan produk sejenis lainnya.

\section{Kepuasan Masyarakat}

Masyarakat adalah seseorang yang kena dampak secara langsung maupun secara tidak langsung terhadap produk atau proses, setiap organisasi tentunya akan menghasilkan produk atau proses. Produk atau proses tersebut akan berdampak pada masyarakat baik dari internal maupun dari eksternal. Masyarakat internal adalah mereka yang terkena dampak produk dan merupakan anggota organisasi yang menghasilkan produk tersebut, sedangkan masyarakat eksternal adalah mereka yang terkena dampak produk, akan tetapi bukan anggota organisasi penghasil produk tersebut. Dewasa ini perhatian terhadap kepuasan maupun ketidak puasan masyarakat telah semakin besar dan menjadi perhatian khusus, karena semakin banyak pihak yang telah menaruh perhatian terhadap kepuasan masyarakat. Pihak yang berhubungan langsung dengan kepuasan masyarakat adalah pemasar, konsumeris dan peneliti perilaku masyarakat. Dalam suatu proses konsumsi, masyarakat tidak akan berhenti hanya sampai pada proses konsumsi. Masyarakat akan melakukan proses evaluasi terhadap konsumsi yang telah dilakukannya. Inilah yang disebut sebagai evaluasi alternative pasca konsumsi. Hasil dari proses evaluasi pasca konsumsi adalah masyarakat merasa puas (satisfaction) atau tidak puas (dissatisfaction) terhadap konsumsi produk atau jasa yang sudah dilakukannya. Kepuasan akan mendorong masyarakat untuk membeli dan mengkonsumsi ulang produk tersebut. 
Sebaliknya perasaan tidak puas akan menyebabkan masyarakat kecewa dan menghentikan pembelian kembali atau mengkonsumsi produk tersebut (Ujang 2004 :321). Kepuasan didefinisikan sebagai persaaan senang atau kecewa seseorang dari membandingkan kinerja produk yang dirasakan dalam hubungan dan harapannya (Kotler 2001 :21). Menurut Zikmund, McLeod dan Gilbert (2003 : 72) kepuasan didefinisikan sebagai evaluasi setelah pembelian hasil dari perbandingan antara harapan sebelum pembelian dengan kinerja sesungguhnya. Menurut Kotler (2001 :21), kepuasan merupakan fungsi dari kinerja yang dirasakan (perceived performance) dan harapan (expectations). Jika kinerja produk atau jasa lebih rendah dari harapan, masyarakat akan merasa tidak puas. Jika kinerja sesuai harapan maka masyarakat akan merasa puas, jika kinerja sampai melebihi harapan, maka masyarakat akan merasa sangat puas (delighted).

\section{Kerangka Pemikiran}

Berikut adalah skema pemikiran yang menggambarkan pengaruh antara variabel penelitian sebagai berikut :

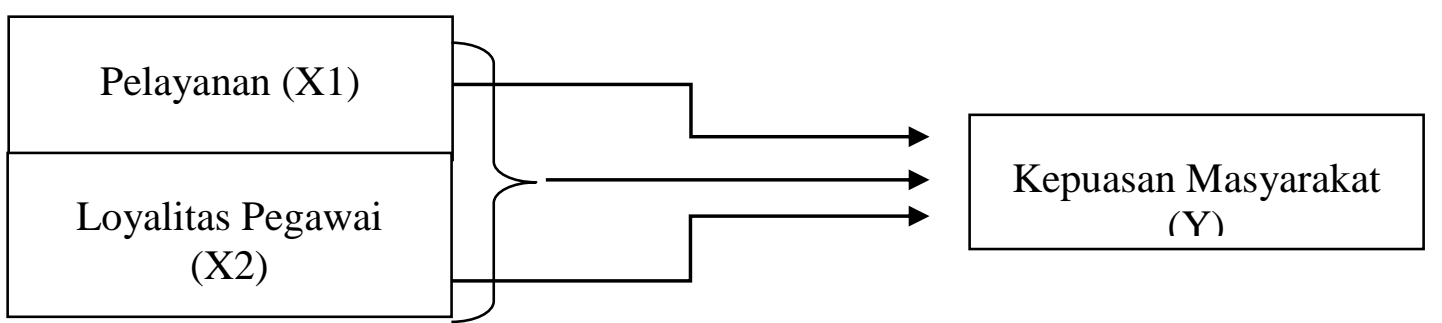

Keterangan :

$\mathrm{X} 1$ : Pelayanan

$\mathrm{X} 2$ : Loyalitas pegawai

Y : Kepuasan masyarakat

\section{Hipotesa Penelitian}

Hipotesis adalah jawaban sementara terhadap perumusan masalah yang akan menjadi penelitian, karena jawaban yang diberikan baru didasarkan pada teori yang relevan dan 
belum didasarkan pada fakta-fakta empiris yang dikumpulkan dari tempat penelitian. Adapun hipotesis dalam penelitian ini adalah :

H1 : Terdapat pengaruh yang postif dan signifikan pelayanan terhadap kepuasan masyarakat.

$\mathrm{H} 2$ :Terdapat pengaruh yang positif dan signifikan loyalitas pegawai terhadap kepuasan masyarakat.

H3 :Terdapat pengaruh yang positif dan signifikan pelayanan dan loalitas pegawai secara bersama-sama terhadap kepuasan masyarakat.

\section{METODE PENELITIAN}

\section{Jenis Penelitian}

Dalam penelitian ini penulis akan menggunakan kategori atau jenis penelitian deskriptif dan kausalitas. Deskriptif adalah suatu metode penelitian yang ditujukan untuk menggambarkan fenomena-fenomena yang ada, yang berlangsung saat ini atau saat yang lampau. Penelitian ini tidak mengadakan manipulasi atau pengubahan pada variabelvariabel bebas, tetapi menggambarkan suatu kondisi apa adanya. Penggambaran kondisi bisa individual atau menggunakan angka-angka. (Sukmadinata, 2006:5). Penelitian deskriptif, bisa mendeskripsikan suatu keadaan saja, tetapi bisa juga mendeskripsikan keadaan dalam tahapan-tahapan perkembangannya, penelitian demikian disebut penelitan perkembangan (Developmental Studies). Dalam penelitian perkembangan ini ada yang bersifat longitudinal atau sepanjang waktu dan ada yang bersifat cross sectional atau dalam potongan waktu. Penelitian kausalitas menurut Rangkuti (2006 : 15) bahwa rancangan penelitian dikelompokkan menjadi dua kelompok, yaitu rancangan penelitian eksplanatori dan konklusif. Rancangan penelitian konklusif selanjutnya dikelompokkan menjadi dua yaitu, rancangan penelitian deskriptif dan rancangan penelitian kausalitas. Rancangan penelitian dengan uji hipotesis dan kausalitas merupakan rancangan penelitian eksplanatori (explanatory research). Penelitian ini menggunakan rancangan penelitian kausalitas yaitu menganalisis hubungan kausalitas antara variabel penelitian sesuai dengan hipotesis yang disusun. Jenis penelitian ini dipilih mengingat tujuan dari peneliti adalah untuk 
menjelaskan hubungan dan pengaruh yang terjadi antar variabel sebagai alat pengumpul data primer. Berdasarkan hipotesis dalam rancangan ini terdapat beberapa variabel yang digunakan antara lain : variabel pelayanan, loyalitas pegawai dan kepuasan masyarakat kemudian menentukan instrument penelitian berdasarkan variabel. Pengumpulan data dilakukan dengan menggunakan metode angket. Teknik analisis yang dipergunakan untuk menganalisis data adalah SPSS. Hasil analisis kemudian diinterpretasikan dan langkah terakhir disimpulkan dan diberi saran.

\section{Populasi dan Teknik Pengambilan Sampel}

Suatu penelitian dapat bersifat penelitian populasi maupun penelitian sampel. Penelitian populasi artinya seluruh obyek atau subyek di dalam wilayah penelitian dijadikan obyek atau subyek penelitian, sedangkan penelitian sampel artinya hanya sebagian dari obyek atau subyek penelitian yang dipilih dan dianggap mewakili keseluruhan populasi. Populasi menurut Sugiyono (2006 : 57) adalah wilayah generalisasi yang terdiri atas obyek atau subyek yang mempunyai kuantitas dan karakteristik tertentu yang ditetapkan oleh peneliti untuk dipelajari dan kemudian ditarik kesimpulannya. Populasi dalam penelitian ini adalah masyarakat yang mengurus Kartu Tanda Penduduk (KTP) di Kelurahan Kelapa Gading Timur di Jakarta Utara. Sampel adalah sebagian dari jumlah dan karakteristik yang dimiliki oleh populasi. Adapun tujuan dari sampel adalah menggunakan sebagian obyek atau subyek penelitian yang diselidiki untuk memperoleh informasi tentang populasi. Untuk menentukan besarnya sampel penelitian yang diperlukan dari jumlah populasi, maka peneliti menggunakan aksidental sampling dimana jumlah sampel berdasarkan kebetulan orang yang ditemui cocok untuk dijadikan sebagai sampel. Adapun jumlah sampel yang akan diambil sebayak 70 orang yaitu masyarakat yang mengurus Kartu Tanda Penduduk di Kelurahan Kelapa Gading Timur di Jakarta Utara.

\section{Operasional Variabel dan Definisi Variabel}

Dalam penelitian ini penulis menggunakan operasionalisasi variabel Kepuasan masyarakat $(\mathrm{Y})$ sebagai dependen variabel pelayanan $\left(\mathrm{X}_{1}\right)$ dan loyalitas pegawai $\left(\mathrm{X}_{2}\right)$ sebagai independent. 


\section{Definisi Variabel}

Variabel penelitian masih merupakan konsep yang abstrak, maka masing-masing variabel perlu dibuat definisi operasionalnya. Adapun definisi operasional dari masingmsing variabel yang diteliti dalam penelitian ini adalah sebagai berikut : 1.Pelayanan (X1) adalah merupakan suatu usaha untuk membantu (mengurus) apa yang diperlukan/membantu apa-apa yang diperlukan oleh orang lain agar terciptanya kepuasan dan keberhasilan yang diinginkan. 2. Loyalitas pegawai (X2) adalah merupakan akibat dari suatu percobaan awal sebuah produk yang diperkuat melalui kepuasan sehingga akan mengarah pada pembelian ulang atau akan datang kembali. 3. Kepuasan masyarakat (Y) merupakan fungsi dari kinerja yang dirasakan (perceived performance) dan harapan (expectations). Jika kinerja produk atau jasa lebih rendah dari harapan, masyarakat akan merasa tidak puas. Jika kinerja sesuai harapan maka masyarakat akan merasa puas, jika kinerja sampai melebihi harapan, maka masyarakat akan merasa sangat puas (delighted).

\section{Skala Pengukuran dan Instrumen Penelitian}

Menurut Sugiyono (2011 : 68) skala pengkukuran variabel ada 4 yaitu Nominal, Ordinal, Interval dan Ratio. Dalam penelitian ini untuk mengetahui satuan nilai atas jawaban responden dalam daftar pertanyaan atau pernyataan, maka penulis menggunakan pengukuran dengan Skala Likert dan menggunakan ordinal yaitu, contoh menyusun skala jawaban dapat dilihat pada tabel 1 sebagai berikut :

\section{Tabel 1 Skala Jawaban Responeden}

\begin{tabular}{|l|c|}
\hline \multicolumn{1}{|c|}{ Skala } & Skor \\
\hline Sangat Baik & 5 \\
\hline Baik & 4 \\
\hline Kurang Baik & 3 \\
\hline Tidak Baik & 2 \\
\hline Sangat Tidak Baik & 1 \\
\hline
\end{tabular}

Sumber :Sugiyono (2011: 68) 


\section{Instrumen Penelitian}

Instrumen penelitian merupakan hal yang sangat penting sebagai bahan analisa yang relevan dengan apa yang ada pada hipotesis guna dilakukan pengujian. Instrumen penelitian yang dipergunakan pada penelitian ini adalah data primer yang merupakan data yang langsung diambil dari objek penelitian dengan menggunakan kuesioner. Kuesioner adalah suatu teknik pengumpulan data yang dilakukan dengan cara memberikan seperangkat pertanyaan atau pertanyaan tertulis pada responden untuk menjawab.

\section{Teknik Pengumpulan Data}

Teknik pengumpulan data merupakan suatu cara pengumpulan data dengan menyebarkan daftar pertanyaan kepada responden dengan harapan mereka akan memberikan respon terhadap daftar pertanyaan tersebut. Dalam melaksanakan pengumpulan data dan informasi yang dibutuhkan sebagai dasar penulisan penelitian, penulis membuat kuisioner yang berisikan pertanyaan dari setiap variabel. Dalam penelitian ini daftar pertanyaan diajukan kepada masyarakat dengan menggunakan skala likert.

\section{Teknik Analisa Data}

Penelitian ini menggunakan statistic deskriptif dengan menggunakan analisis regresi berganda dengan pengolahan data menggunakan SPSS for Windows. dimaksudkan untuk mengukur besarnya pengaruh pelayanan, loyalitas pegawai baik secara parsial maupun secara bersama-sama terhadap kepuasan masarakat.

\section{HASIL DAN PEMBAHASAN}

\section{Uji Validitas dan Reliabilitas}

Uji validitas ini dilakukan dengan tujuan untuk mengetahui kesahihan dari angket atau kuesioner. Kesahihan disini mempunyai arti kuesioner atau angket yang dipergunakan mampu untuk mengukur apa yang seharusnya diukur. Suatu kuesioner dikatakan valid (handal) jika jawaban seseorang terhadap pertanyaan yang terdapat dalam kuesioner tersebut adalah konsisten atau stabil dari waktu ke waktu. Uji validitas ini bisa dilakukan dengan membandingkan nilai $r$ hitung dengan nilai $r$ tabel. Nilai $r$ hitung diambil dari output SPSS Cronbach Alpha pada kolom Correlated Item-Total Correlation. Sedangkan 
nilai $\mathrm{r}$ tabel diambil dengan menggunakan rumus $\mathrm{df}=\mathrm{n}-8$ (Ghozali, $2006: 45)$. Yaitu $\mathrm{df}=$ $70-8=62$, sehingga menghasilkan nilai $r$ tabel sebesar 0,244 . Untuk hasil lengkap dari uji validasi dapat dilihat pada tabel 2 sampai dengan tabel 9 sebagai berikut:

\section{Tabel 2 Uji Validitas Variabel Pelayanan (X1)}

Item-Total Statistics

\begin{tabular}{|l|r|r|r|r|r|}
\hline & $\begin{array}{c}\text { Scale Mean } \\
\text { if Item } \\
\text { Deleted }\end{array}$ & $\begin{array}{c}\text { Scale } \\
\text { Variance if } \\
\text { Item Deleted }\end{array}$ & $\begin{array}{c}\text { Corrected Item- } \\
\text { Total } \\
\text { Correlation }\end{array}$ & $\begin{array}{c}\text { Squared } \\
\text { Multiple } \\
\text { Correlation }\end{array}$ & $\begin{array}{c}\text { Cronbach's } \\
\text { Alpha if Item } \\
\text { Deleted }\end{array}$ \\
\hline Pelayanan01 & 27.0429 & 10.042 & .401 & .246 & .753 \\
Pelayanan02 & 27.0286 & 10.173 & .415 & .269 & .751 \\
Pelayanan03 & 27.0857 & 9.442 & .552 & .532 & .727 \\
Pelayanan04 & 27.0714 & 9.459 & .492 & .524 & .738 \\
Pelayanan05 & 27.0714 & 9.604 & .540 & .331 & .730 \\
Pelayanan06 & 27.0000 & 10.203 & .365 & .285 & .759 \\
Pelayanan07 & 27.0714 & 9.430 & .464 & .320 & .744 \\
Pelayanan08 & 27.0286 & 9.564 & .508 & .366 & .735 \\
\hline
\end{tabular}

Sumber : Data penelitian yang diolah 2016

Tabel 3 Uji Validitas Variabel Loyalitas Pegawai (X2)

Item-Total Statistics

\begin{tabular}{|c|c|c|c|c|c|}
\hline & $\begin{array}{c}\text { Scale Mean } \\
\text { if Item } \\
\text { Deleted }\end{array}$ & $\begin{array}{c}\text { Scale } \\
\text { Variance if } \\
\text { Item Deleted }\end{array}$ & $\begin{array}{c}\text { Corrected Item- } \\
\text { Total } \\
\text { Correlation }\end{array}$ & $\begin{array}{c}\text { Squared } \\
\text { Multiple } \\
\text { Correlation }\end{array}$ & $\begin{array}{l}\text { Cronbach's } \\
\text { Alpha if Item } \\
\text { Deleted }\end{array}$ \\
\hline $\begin{array}{l}\text { Loyalitas } \\
01\end{array}$ & 27.0429 & 10.042 & .401 & .246 & .753 \\
\hline $\begin{array}{l}\text { Loyalitas } \\
02\end{array}$ & 27.0286 & 10.173 & .415 & .269 & .751 \\
\hline $\begin{array}{l}\text { Loyalitas } \\
03\end{array}$ & 27.0857 & 9.442 & .552 & .532 & .727 \\
\hline $\begin{array}{l}\text { Loyalitas } \\
04\end{array}$ & 27.0714 & 9.459 & .492 & .524 & .738 \\
\hline $\begin{array}{l}\text { Loyalitas } \\
05\end{array}$ & 27.0714 & 9.604 & .540 & .331 & .730 \\
\hline
\end{tabular}




\begin{tabular}{|c|c|c|c|c|c|}
\hline $\begin{array}{l}\text { Loyalitas } \\
06\end{array}$ & 27.0000 & 10.203 & .365 & .285 & .759 \\
\hline $\begin{array}{l}\text { Loyalitas } \\
07\end{array}$ & 27.0714 & 9.430 & .464 & .320 & .744 \\
\hline $\begin{array}{l}\text { Loyalitas } \\
08\end{array}$ & 27.0286 & 9.564 & .508 & .366 & \\
\hline
\end{tabular}

Sumber : Data penelitian yang diolah 2016

Tabel 4 Uji Validitas Variabel Kepuasan Masyarakat (Y)

Item-Total Statistics

\begin{tabular}{|c|c|c|c|c|c|}
\hline & $\begin{array}{c}\text { Scale Mean } \\
\text { if Item } \\
\text { Deleted }\end{array}$ & $\begin{array}{c}\text { Scale } \\
\text { Variance if } \\
\text { Item Deleted }\end{array}$ & $\begin{array}{c}\text { Corrected Item- } \\
\text { Total } \\
\text { Correlation }\end{array}$ & $\begin{array}{c}\text { Squared } \\
\text { Multiple } \\
\text { Correlation }\end{array}$ & $\begin{array}{l}\text { Cronbach's } \\
\text { Alpha if Item } \\
\text { Deleted }\end{array}$ \\
\hline $\begin{array}{l}\text { Kepuasan } \\
01\end{array}$ & 26.8429 & 11.004 & .403 & .298 & .836 \\
\hline $\begin{array}{l}\text { Kepuasan } \\
02\end{array}$ & 26.9143 & 10.485 & .497 & .324 & .825 \\
\hline $\begin{array}{l}\text { Kepuasan } \\
03\end{array}$ & 26.9000 & 10.584 & .558 & .358 & .817 \\
\hline $\begin{array}{l}\text { Kepuasan } \\
04\end{array}$ & 26.8571 & 10.298 & .581 & .518 & .814 \\
\hline $\begin{array}{l}\text { Kepuasan } \\
05\end{array}$ & 26.9000 & 10.729 & .623 & .411 & .813 \\
\hline $\begin{array}{l}\text { Kepuasan } \\
06\end{array}$ & 26.9143 & 9.268 & .645 & .452 & .806 \\
\hline $\begin{array}{l}\text { Kepuasan } \\
07\end{array}$ & 26.8857 & 10.074 & .548 & .451 & .819 \\
\hline $\begin{array}{l}\text { Kepuasan } \\
08\end{array}$ & 26.8857 & 9.494 & .696 & .515 & .798 \\
\hline
\end{tabular}

Sumber : Data penelitian yang diolah 2016

\section{Uji Reliabilitas}

Uji realibilitas merupakan uji kehandalan yang bertujuan untuk mengetahui seberapa jauh sebuah alat ukur dapat diandalkan atau dipercaya. Pengujian realibilitas terhadap seluruh item/pertanyaan yang dipergunakan dalam penelitian ini akan menggunakan formula 
cronbach alpha (koefisien alpha cronbach), dimana secara umum yang dianggap reliabel apabila nilai alpha cronbachnya > 0,70 (Nunnaly dalam Ghozali, 2006 : 42). Hasil lengkap uji reliabilitas dapat dilihat pada tabel 5 berikut ini:

Tabel 5 Hasil Uji Reliabilitas Variabel Pelayanan (X1), Loyalitas Pegawai (X2) Terhadap Kepuasan Masyarakat (Y)

\begin{tabular}{|l|r|r|}
\hline Variabel & Cronbach's Alpha & Keterangan \\
\hline Pelayanan (X1) & 0.767 & Reliabel \\
Loyalitas Pegawai (X2) & 0.861 & Reliabel \\
Kepuasan Masyarakat (Y) & 0.836 & Reliabel \\
\hline
\end{tabular}

Sumber : Data penelitian yang diolah 2016

Dari tabel 5 di atas dapat diketahui bahwa nilai Cronbach Alpha dari seluruh variabel yang diujikan nilainya di atas 0,70 maka dapat disimpulkan bahwa seluruh variabel dalam penelitian ini lolos dalam uji reliabilitas dan dinyatakan reliabel.

\section{Uji Hipotesis Parsial Pelayanan ( $\left.\mathbf{X}_{1}\right)$ Terhadap Kepuasan Masyarakat (Y)}

Uji parsial atau sederhana (Uji t) pada dasarnya menunjukkan seberapa jauh atau besar pengaruh suatu variabel independen secara parsial atau sederhana dalam menerangkan variasi variabel dependen (Ghozali, 2011 : 98). Hasil perhitungan SPSS uji signifikan variabel pelayanan terhadap kepuasan masyarakat dalam mengurus Kartu Tanda Penduduk dapat dilihat pada tabel 6 di bawah ini adalah sebagai berikut :

Tabel 6 Uji Hipotesis Individual Pelayanan $\left(X_{1}\right)$ Terhadap Kepuasan Masyarakat (Y)

Coefficients $^{\mathrm{a}}$

\begin{tabular}{|rr|r|r|r|r|r|}
\hline \multirow{2}{*}{ Model } & \multicolumn{2}{|c|}{$\begin{array}{c}\text { Unstandardized } \\
\text { Coefficients }\end{array}$} & \multicolumn{1}{c|}{$\begin{array}{c}\text { Standardized } \\
\text { Coefficients }\end{array}$} & & \\
\cline { 2 - 5 } & \multicolumn{1}{|c|}{ B } & Std. Error & \multicolumn{1}{c|}{ Beta } & \multicolumn{1}{c|}{$\mathrm{t}$} & \multicolumn{1}{c|}{ Sig. } \\
\hline 1 & (Constant) & 8.859 & 1.830 & & 4.841 & .000 \\
& Pelayanan & .735 & .059 & .835 & 12.498 & .000 \\
\hline
\end{tabular}

a. Dependent Variable: Kepuasan 
Berdasarkan hasil analisis dengan menggunakan program SPSS menunjukkan hasil bahwa nilai $t_{\text {hitung }}$ (pelayanan) sebesar 12,498 dengan signifikan t bernilai 0,000 sedangkan nilai $t_{\text {tabel }}$ sebesar 1,676 dan koefisien regresi sebesar 0,735 karena nilai $t_{\text {hitung }}=$ $12,498>\mathrm{t}_{\text {tabel }}=1,676$ atau 0,000 $<0,05$ maka Ho ditolak dan Ha diterima. Dengan demikian maka hipotesis pertama dalam penelitian ini adalah pelayanan berpengarih positif dan signifikan terhadap kepuasan masyarakat dalam mengurus Kartu Tanda Penduduk di Kelurahan Kelapa Gading Timur di Jakarta Utara.

\section{Uji Hipotesis Parsial Loyalitas (X) Terhadap Kepuasan Masyarakat (Y)}

Uji parsial atau sederhana (Uji t) pada dasarnya menunjukkan seberapa jauh atau besar pengaruh suatu variabel independen secara parsial atau sederhana dalam menerangkan variasi variabel dependen. Hasil perhitungan SPSS uji signifikan variabel loyalitas pegawai terhadap kepuasan masyarakat dalam mengurus Kartu Tanda Penduduk dapat dilihat pada tabel 7 di bawah ini adalah sebagai berikut :

Tabel 7 Uji Hipotesis Individual Loyalitas (X2) Terhadap Kepuasan Masyarakat (Y)

\section{Coefficients $^{\mathrm{a}}$}

\begin{tabular}{|c|c|c|c|c|c|c|}
\hline \multirow{2}{*}{\multicolumn{2}{|c|}{ Model }} & \multicolumn{2}{|c|}{$\begin{array}{c}\text { Unstandardized } \\
\text { Coefficients }\end{array}$} & \multirow{2}{*}{\begin{tabular}{|c|}
$\begin{array}{c}\text { Standardized } \\
\text { Coefficients }\end{array}$ \\
Beta
\end{tabular}} & \multirow[b]{2}{*}{$\mathrm{t}$} & \multirow[b]{2}{*}{ Sig. } \\
\hline & & B & Std. Error & & & \\
\hline 1 & (Constant) & 11.137 & 2.013 & & 5.533 & .000 \\
\hline & Loyalitas & .665 & .065 & .778 & 10.227 & .000 \\
\hline
\end{tabular}

a. Dependent Variable: Kepuasan

Berdasarkan hasil analisis dengan menggunakan program SPSS menunjukkan hasil bahwa nilai $t_{\text {hitung }}$ (loyalitas) sebesar 10,227 dengan signifikan $\mathrm{t}$ sebesar 0,000 sedangkan nilai $t_{\text {tabel }}$ sebesar 1,676 dan koefisien regresi sebesar 0,665 karena nilai $t_{\text {hitung }}=$ $10,227>\mathrm{t}_{\text {tabel }}=1,676$ atau $0,000<0,05$ maka Ho ditolak dan Ha diterima. Dengan demikian maka hipotesis kedua dalam penelitian ini adalah loyalitas pegawai berpengarih positif dan signifikan terhadap kepuasan masyarakat dalam mengurus Kartu Tanda Penduduk diKelurahan Kelapa Gading Timur di Jakarta Utara. 


\section{Uji Hipotesis Simultan Antara Pelayanan dan Loyalitas Pegawai ( $\left.\mathbf{X}_{2}\right)$ Terhadap}

\section{Kepuasan Masyarakat (Y)}

Uji simultan atau bersama-sama (Uji F) pada dasarnya menunjukkan seberapa jauh atau besar pengaruh suatu variabel independen secara smultan atau berama-sama dalam menerangkan variasi variabel dependen. Hasil perhitungan SPSS uji signifikan variabel pelayanan dan loyalitas pegawai terhadap kepuasan masyarakat dalam mengurus Kartu Tanda Penduduk adalah sebagai berikut : Pembuktian hipotesis ketiga secara simultan dapat dilihat pada tabel Anova pada kolom Sig. 0,000 < 0,05, yang berarti bahwa variabel pelayanan dan loyalitas pegawai secara bersama - sama berpengaruh signifikan terhadap kepuasan masyarakat dalam mengurus Kartu Tanda Penduduk di Kelurah Kelapa Gading Timur di Jakarta Utara. Cara yang kedua adalah dengan membandingkan antara $\mathrm{F}$ hitung dengan $F$ tabel. Kolom $F$ hitung sebesar 87,290 $>F_{\text {tabel }}$ 3,16 yang berarti bahwa variabel pelayanan dan loyallitas pegawai secara bersama-sama berpengaruh signifikan terhadap kepuasan masyarakat dalam mengurus Kartu Tanda Penduduk di Kelurahan Kelapa Gading Timur di Jakarta Utara. Kesimpulannya adalah bahwa pelayanan dan loyalitas pegawai secara bersama -sama berpengaruh signifikan terhadap kepuasan masyarakat dalam mengurus Kartu Tanda Penduduk di Kelurahan Kelapa Gading Timur di Jakarta Utara. Berdasarkan pembuktian ini maka dapat disimpulkan Hipotesis Ketiga $\left(\mathrm{H}_{3}\right)$ diterima. Pembuktian hipotesis selanjutnya, ditampilkan output SPSS pada tabel 8 di bawah ini sebagai berikut:

Tabel 8 Uji Hipotesis Secara Simultan Pelayanan (X1) dan Loyalitas (X2) Terhadap Kepuasan Masyarakat (Y)

\section{ANOVA ${ }^{\text {b }}$}

\begin{tabular}{|l|r|r|r|r|r|}
\hline Model & Sum of Squares & df & Mean Square & F & Sig. \\
\hline 1 Regression & 476.222 & 2 & 238.111 & 87.290 & $.000^{\mathrm{a}}$ \\
Residual & 182.764 & 67 & 2.728 & & \\
Total & 658.986 & 69 & & & \\
\hline
\end{tabular}

a. Predictors: (Constant), Loyalitas, Pelayanan

b. Dependent Variable: Kepuasan 


\section{Coefficients $^{\mathrm{a}}$}

\begin{tabular}{|c|c|c|c|c|c|}
\hline \multirow[b]{2}{*}{ Model } & \multicolumn{2}{|c|}{ Unstandardized Coefficients } & \multirow{2}{*}{\begin{tabular}{|c|} 
Standardized Coefficients \\
Beta
\end{tabular}} & \multirow[b]{2}{*}{$\mathrm{t}$} & \multirow[b]{2}{*}{ Sig. } \\
\hline & $\mathrm{B}$ & Std. Error & & & \\
\hline 1 (Constant) & 7.764 & 1.816 & & 4.275 & .000 \\
\hline Pelayanan & .530 & .100 & .601 & 5.308 & .000 \\
\hline Loyalitas & .242 & .097 & .284 & 2.504 & .015 \\
\hline
\end{tabular}

a. Dependent Variable: Kepuasan

Berdasarkan hasil analisis dengan menggunakan program SPSS menunjukkan hasil bahwa koefisien regresi variabel pelayanan $\left(X_{1}\right)$ sebesar 0,530 nilai konstanta sebesar 7,764 hal ini menunjukkan bahwa apabila variabel pelayanan tidak ada $\left(\mathrm{X}_{1}=0\right)$ maka variabel kepuasan masyarakat (Y) sebesar 7,764 dan loyalitas pegawai (X2) mempengeruhi oleh kepuasan masyarakat sebesar 0,242. Setelah nilai koefisien regresi dan nilai kontanta diketahui maka model regresi linier adalah $Y=7.764+0,530_{1}+0,242 \mathrm{X}_{2}$.

\section{Koefisien Determinasi}

Koefisien determinasi adalah kemampuan seluruh variabel bebas dalam menjelaskan variable terikat. Untuk mengetahui kemampuan variabel pelayanan dan loyalitas pegawai dalam menjelaskan kepuasan masyarakat dalam mengrus Kartu Tanda Penduduk di Kelurahan Kepala Gading Timur di Jakarta Utara, disajikan model summary output SPSS pada tabel 9 di bawah ini sebagai berikut:

Tabel 9 Koefisien Determinasi Pelayanan (X1) dan Loyalitas Pegawai Terhadap Kepuasan Masyarakat (Y)

Model Summary

\begin{tabular}{|l|l|r|r|r|}
\hline Model & \multicolumn{1}{|c|}{$\mathrm{R}$} & R Square & Adjusted R Square & Std. Error of the Estimate \\
\hline 1 & $.850^{\mathrm{a}}$ & .723 & .714 & 1.65161 \\
\hline
\end{tabular}

a. Predictors: (Constant), Loyalitas, Pelayanan

Model summary menunjukkan Koefisien Determinasi Adjustend R Square sebesar 0,714 atau sebesar $71,4 \%$ yang berarti bahwa kemampuan variabel pelayanan dan loyalitas pegawai dapat menjelaskan kepuaan masyarakat dalam mengurus Kartu Tanda Penduduk di Kelurahan Kelapa Gading Timur di Jakarta Utara adalah sebesar 71,4\%. Sedangkan 
sisanya sebesar $28,6 \%$ dijelaskan oleh variabel lain diluar dari variabel penelitian ini. Koefisien determinasi menggunakan Adjustend $R$ Square, karena variabel bebas lebih dari satu (regresi berganda), sedangkan apabila variabel bebas hanya satu (regresi sederhana), maka koefisien determinasi akan dihitung dari $r$ square.

\section{KESIMPULAN}

Berdasarkan hasil analisis yang dilakukan pada penelitian ini, maka terdapat tiga hipotesis yang diajukan dalam penelitian ini dan model analisis yang digunakan dalam penelitian ini adalah regresi linier sederhana dan berganda. Dari hasil analisis data dapat diperoleh kesimpulan sebagai berikut :

1. Variabel pelayanan berpengaruh positif dan signifikan terhadap kepuasan masyarakat dalam mengurus Kartu Tanda Penduduk di Kelurahan Kelapa Gading Timur di Jakarta Utara. Hal ini berarti bahwa di Kelurahan Kelapa Gading Timur di Jakarta Utara sudah bisa menyelaraskan program pelayanan dengan realisasi.

2. Loyalitas pegawai berpengaruh positif dan signifikan terhadap kepuasan masyarakat dalam mengurus Kartu Tanda Penduduk di Kelurahan Kelapa Gading Timur di Jakarta Utara, hal ini harus dipertahankan dan ditingkatkan. Kepuasan masyarakat sudah bisa dicapai melalui peningkatan loyalitas pegawai.

3. Secara bersama - sama, variabel pelayanan dan loyalitas pegawai berpengaruh positih dan signifikan terhadap kepuasan masyarakat dalam mengurus Kartu Tanda Penduduk di Kelurahan Kelapa Gading Timur di Jakarta Utara. Hal ini berarti variabel pelayanan bilamana didukung oleh loyalitas pegawai yang baik, maka akan menghasilkan sinergi yang baik untuk mencapai kepuasan masyarakat.

\section{SARAN}

Memperhatikan adanya beberapa keterbatasan seperti yang telah disampaikan maka bagi penelitian selanjutnya perlu memperhatikan beberapa saran berikut ini:

1. Dari hasil penelitian yang dilakukan, variabel yang paling dominan dalam mempengaruhi kepuasan masyarakat yaitu variabel pelayanan. Dukungan dari pimpinan sangat mempengaruhi kepuasan masyarakat dalam mengurus Kartu Tanda 
Penduduk. Dukungan lebih yang diberikan oleh pimpinan dapat membuat pegawai merasa nyaman dalam bekerja dan pegawai diberi tanggungjawab lebih sehingga dapat memaksimalkan kemampuannya untuk bekerja lebih baik sehingga dapat meningkatkan kepuasan bagi masyarakat.

2. Peneliti selanjutnya disarankan untuk melakukan wawancara secara langsung atas pertanyaan di dalam kuisioner penelitian.

3. Untuk penelitian selanjutnya, disarankan agar menambah variabel bebas yang lain seperti lingkungan kerja, kebijakan publik dan lain sebagainya. Agar peneliti selanjutnya mau melakukan penyempurnaan kuesioner ini, serta melakukan pemilihan waktu yang tepat ketika menyebarkan kuesioner.

\section{DAFTAR PUSTAKA}

Angipora. P Marius., Dasar-Dasar Pemasaran,2002., PT. Raja Grafindo Persada., Jakarta

Desjardins, Yoseph, An Introduction to Business Ethics, Mc Graw Hill, 2006

Djarwanto., Drs. dkk., Statistik Induktif., 2003., BPFE., Yogyakarta.

Ghozali, Imam, Aplikai Analisis Multivarite dengan SPSS, Cetakan Keempat, Badan Penerbit Universitas Diponegoro, Semarang, 2006

Gie, The Liang, Administrasi Perkantoran Modern, Liberty, Yogyakarta, 2008

Griffin, Jill, 2005, Customer Loyalty : How to Earn It, How to Keep It, Lexington Books, Singapore, p : 4,13,18,31,35,54,89,108,121,139,141,162.169.

Handayaningrat, Pengantar Studi Ilmu Administrasi dan Manajemen, Jakarta, Haji Masagung, 2006

Hill, Nigel, Handbook of Customer Satisfaction Measurement, Gower Publishing Limited, 2006

Keegan Warren. J., Manajemen Pemasaran Global., Jilid 1., Prenhallindo., Jakarta., 1996.

Kotler.Philip., Manajemen Pemasaran (Analisis, Perencanaan, Implementasi, dan Kontrol)., Prenhallindo., Jakarta., 2002. 
Kumorotomo, Wahyudi, Etika Administrasi Negara, Radja Grafindo Persada, Jakarta, 2005

Kuncoro, Mudrajad, Metode riset untuk bisnis \& ekonomi, Erlanggan, Jakarta, 2003

Lawrence, Jauch and R. William F. Glueck., Manajemen Strategi dan Kebijakan Perusahaan, Edisi Ketiga, Erlangga., Bandung., 2008.

Lee, Jangwoo and Miller, Danny, 2006. Strategy, Environment And Performance In Two Technical Contexts: Contingency Theory In Korea, Organization Studies(Walter De Gruyter Gmb And Co.K.G.) Vol. 17. No.5. pp729-751

Rangkuti, Freddy, Strategi Promosi yang Kreatif dan Analisis Kasus Integrated Marketing Communication, Jakarta : PT. Gramedia Pustaka Utama, 2009

Saladin Djaslim., Intisari Pemasaran dan Unsur-Unsur Pemasaran., Linda Karya., Bandung., 2002.

Santoso S \& Tjiptono F., Riset Pemasaran (Konsep dan Aplikasi Dengan SPSS)., Elex Media Komputindo., Jakarta.,2002.

Sitepu. Nirwana., Analisis Jalur (Path Analysis) 2004., Unit Pelayanan Statistika Jurusan Statistika., FMIPA UNPAD., Bandung.

Sri Wahyudi. A., Manajemen Strategik., 2005., Binarupa Aksara., Jakarta.

Sugiyono., Metoda Penelitian Administrasi., Alfabeta., Bandung., 2006.

Tjiptono Fandy., 2006 Manajemen Jasa, Edisi Pertama, Penerbit Andi, Yogyakarta, hlm : $5,41,42$. 